\title{
50 年の歩み
}

\section{日本図学会年表（1965～2016）}

\author{
庶務担当理事 横山ゆり Yurika YOKOYAMA \\ 庶務担当理事 椎名 久美子 Kumiko SHIINA \\ 編集担当理事 種田 元晴 Motoharu TANEDA
}

1）本年表は 1965 年 12 月から 2016 年 12 月までの日本図学会の活動をまとめたもので, 支部活動は原則として載せてい ない.「巻一号 (通号)」は，関連情報が記載された『図学研究』の巻号（通号）である. 会員数として記載されてい るのは, 名誉会員, 正会員, 学生会員の合計である.

2）記載は, 『図学研究』および『創立 20 周年記念号』の年表（1965～1987 年）（非公式版のまとめとして野口徹氏によ る作成), 『創立 30 周年記念号』の年表（1987 1996 年）（安達裕之氏による作成）、『創立 40 周年記念号』の年表 （1997～2006 年）（横山ゆりか作成）に基づいてまとめると共に，2007～2016 年までの情報を加えたものである.

\begin{tabular}{|c|c|c|c|}
\hline 年 & 月 & & $\begin{array}{l}\text { 巻-号 } \\
\text { (通号) }\end{array}$ \\
\hline $\begin{array}{l}1965 \\
(\mathrm{~S} .40)\end{array}$ & 12 & 図学にかかわる全国的な連絡組織，研究組織創設の要請 & \\
\hline \multirow[t]{2}{*}{$\begin{array}{l}1966 \\
(\mathrm{~S} .41)\end{array}$} & 4 & $\begin{array}{l}\text { 北海道大学, 東北大学, 東京大学, 名古屋大学, 京都大学, 神戸大学, 九州大学の図学担当 } \\
\text { 教員が㤅談会を開催 (4月 } 3 \text { 日, 於 本郷 - 学士会館) }\end{array}$ & \\
\hline & 12 & 発起人会開催, 23 名参集, 組織の構成を理工系に芸術・美術系を加えた分野とする & \\
\hline \multirow{6}{*}{$\begin{array}{l}1967 \\
(\mathrm{~S} .42)\end{array}$} & \multirow[t]{2}{*}{5} & 創立総会準備委員会 & \\
\hline & & $\begin{array}{l}\text { 日本図学研究会設立総会 }(5 \text { 月 } 21 \text { 日, 於 東京電機大学 }) \\
\text { 会員数 } 93 \text { 名, 初代会長 (須藤利一) 決定. } \\
\text { 趣意書 }:\lceil\text { 明治の教育制度確立以来, 図学が理工系ならびに美術系教育の主要な教科の一つ } \\
\text { に数えられてきた. しかるに, その教育・研究活動を交流, 促進すべき独立した組織をかき, } \\
\text { また戦後の学制改革にも十分に対処しないまま推移したが, 戦後 } 20 \text { 年をへた今日に至って } \\
\text { …..全国的組織化の機運が到来」「図学とは図法幾何学だけでなく, 各種の図形教育ならび } \\
\text { に Engineering Drawing, Graphicsなど図形及びその応用に関するあらゆる分野を包括」「図 } \\
\text { 学担当教官だけでなく, 理工系の各分野ならびに造形芸術・応用心理学の分野で図形に関連 } \\
\text { する教育・研究に関心をもつすへての人々の入会を期待」 } \\
\text { 座談会「諸外国の図学教育の動向」「図学教育の現状」開催 }\end{array}$ & \\
\hline & \multirow[t]{2}{*}{6} & 会報 - 会誌の発行決定, 英文学会名〈The Japan Society for Graphic Science〉提案 & \\
\hline & & 日本図学研究会関西支部設立（於 京都大学） & \\
\hline & \multirow[t]{2}{*}{7} & 東海地区 活動開始 & \\
\hline & & 第 1 回例会（於 東京大学） & \\
\hline
\end{tabular}




\begin{tabular}{|c|c|c|c|}
\hline 年 & 月 & & $\begin{array}{l}\text { 巻 - 号 } \\
\text { (通号) }\end{array}$ \\
\hline \multirow{5}{*}{$\begin{array}{l}1967 \\
(\mathrm{~S} .42)\end{array}$} & \multirow[t]{2}{*}{9} & 会誌英文名〈Journal of Graphic Science of Japan〉提案 & \\
\hline & & 第 2 回例会（於 東京電機大学） & \\
\hline & 10 & 第 3 回例会（於 東京大学） & \\
\hline & \multirow[t]{2}{*}{11} & 第 4 回例会（於 東京電機大学） & \\
\hline & & 会誌『図学研究』第 1 号創刊（題字は小山清男氏), 以降年 2 回 (3 月, 9 月）発行 & \\
\hline \multirow{10}{*}{$\begin{array}{l}1968 \\
(\mathrm{~S} .43)\end{array}$} & 1 & 第 5 回例会（於 東京電機大学） & \\
\hline & 3 & 『図学研究』第 2 号刊行．図学教育の実態調査報告が掲載される & $2-1(2)$ \\
\hline & \multirow[t]{2}{*}{4} & 日本図学研究会 1968 年度大会開催（於 大阪府立大学） & $2-2(3)$ \\
\hline & & 名誉会員制実施 $(7$ 名 $)$, 文献委員会 - 用語委員会設置 & \\
\hline & 7 & 第 6 回例会（於 国土地理院） & \\
\hline & 8 & 九州地区第 1 回講習会開催 & \\
\hline & \multirow[t]{2}{*}{9} & 第 7 回例会（於 東京電機大学） & \\
\hline & & 『図学研究』第 3 号刊行. & \\
\hline & 10 & 大会・例会における研究発表の会誌への転載決定 & \\
\hline & 11 & 東大闘争の拡大により事務局の移動・移転となる & \\
\hline \multirow{9}{*}{$\begin{array}{l}1969 \\
(\mathrm{~S} .44)\end{array}$} & 1 & 東大闘争激化により事務局閉鎖 & \\
\hline & 2 & 第 8 回例会（於 三菱重工横浜造船所） & \\
\hline & 3 & 『図学研究』第 4 号刊行. & \\
\hline & 5 & $\begin{array}{l}\text { 日本図学研究会 } 1969 \text { 年度大会開催（於 東京電機大学） } \\
\text { 会員数 } 190 \text { 名, 会長 (須藤利一) 再選 } \\
\text { 特別講演「コンピュータ・グラフィックス」(穂坂衛 })\end{array}$ & $3-2(5)$ \\
\hline & 6 & 第 29 回役員会にて会名変更〈日本図学会〉提案決定 & \\
\hline & 7 & 日本図学会と改称（日本学術会議に学術研究団体として登録） & \\
\hline & 10 & 『図学研究』第 5 号刊行. & \\
\hline & \multirow[t]{2}{*}{11} & 財政状況の悪化が判明. 会誌 6 号の発行が危ぶまれる & \\
\hline & & 第 9 回例会（武蔵工業展示会見学） & \\
\hline \multirow[t]{2}{*}{$\begin{array}{l}1970 \\
(\mathrm{~S} .45)\end{array}$} & 5 & $\begin{array}{l}\text { 日本図学会 } 1970 \text { 年度大会開催（於 大同工業大学） } \\
\text { 会員数 } 190 \text { 名, 会費值上げ } \\
\text { シンポジウム「図学教育を如何に考えるか」開催. } \\
\text { ホーエンベルグ教授 (グラーツ工科大学) 特別講演は来日不能のため中止. }\end{array}$ & \\
\hline & 8 & $\begin{array}{l}\text { 第 } 10 \text { 回例会（於 新潟県六日町） } \\
「 \text { 「゙ラフィック・サイエンスについて」(南日朗) }\end{array}$ & \\
\hline
\end{tabular}




\section{0 年の歩み}

\begin{tabular}{|c|c|c|c|}
\hline 年 & 月 & & $\begin{array}{l}\text { 巻 - 号 } \\
\text { (通号) }\end{array}$ \\
\hline \multirow{5}{*}{$\begin{array}{l}1971 \\
(\mathrm{~S} .46)\end{array}$} & 1 & 会報 13 号に図学文献（国内雑誌）リスト掲載 & \\
\hline & 5 & $\begin{array}{l}\text { 日本図学会 } 1971 \text { 年度大会開催（於 東京大学） } \\
\text { 会員数 } 189 \text { 名, 役員改選（会長：幸田彰), 図学論文賞検討委員会設置 } \\
\text { 講演「帰朝報告・アメリカ, カナダの図学教育について」(磯田浩) }\end{array}$ & \\
\hline & 8 & 第 11 回例会（於 浜松） & \\
\hline & \multirow[t]{2}{*}{11} & 図学及び製図教育研究委員会発足, 四学試験問題・製図課題アンケート調査決める & \\
\hline & & $\begin{array}{l}\text { 会報 } 16 \text { 号に図学文献（追加分）掲載. } \\
\text { 用語委員会再発足 }\end{array}$ & \\
\hline \multirow{4}{*}{$\begin{array}{l}1972 \\
(\mathrm{~S} .47)\end{array}$} & 1 & 会報 18 号に図学文献リスト掲載 & \\
\hline & 5 & $\begin{array}{l}\text { 日本図学会 } 1972 \text { 年度大会開催（於 神戸大学） } \\
\text { 会員数 } 194 \text { 名 } \\
\text { 特別講演「ホログラフィについて」(梯上雅和） }\end{array}$ & $6-2(11)$ \\
\hline & 8 & 第 12 回例会（於 日立製作所日立工場） & \\
\hline & 12 & PR 用会誌（号外）の発行決める & \\
\hline \multirow[t]{5}{*}{$\begin{array}{l}1973 \\
(\mathrm{~S} .48)\end{array}$} & 5 & $\begin{array}{l}\text { 日本図学会 } 1973 \text { 年度大会開催（於 青山学院大学） } \\
\text { 役員改選 (会長 : 幸田彰), 会員数 } 204 \text { 名, 会費値上げ }\end{array}$ & 7-2(13) \\
\hline & & 臨時委員会・コンピュータ・グラフィックス委員会設置（関西） & \\
\hline & 7 & 日本図学会東北支部設立（於 東北大学） & \\
\hline & 8 & $\begin{array}{l}\text { 第 } 13 \text { 回例会（関西支部合同）（於 神戸） } \\
\text { シンポジゥム「図学の領域と課題」, パネル討論〈画法幾何学〉〈構成幾何学〉〈図形知覚〉 } \\
\text { 〈幾何学と図学〉〈コンピュータと図学〉〈美術と図学〉 }\end{array}$ & \\
\hline & 12 & 第 13 回例会（武蔵工業見学会） & \\
\hline \multirow[t]{3}{*}{$\begin{array}{l}1974 \\
\text { (S.49) }\end{array}$} & 5 & $\begin{array}{l}\text { 日本図学会 } 1974 \text { 年度大会開催（於 京都大学） } \\
\text { 会員数 } 219 \text { 名, 会費值上げ } \\
\text { 特別講演「コンピュータと画像処理」(坂井利之) }\end{array}$ & $8-2(15)$ \\
\hline & & 『図学研究』投稿規定改定, 日本図学会賞授与規定作成 & \\
\hline & 11 & 第 14 回例会（三菱鉛筆横浜事業所見学） & \\
\hline \multirow[t]{5}{*}{$\begin{array}{l}1975 \\
\text { (S.50) }\end{array}$} & 5 & $\begin{array}{l}\text { 日本図学会 } 1975 \text { 年度大会開催（於 東京藝術大学） } \\
\text { 会員数 } 226 \text { 名, 役員改選（会長 : 綾井九州彦） } \\
\text { 特別講演「迎賓館の天井画について」(寺田春式） }\end{array}$ & $9-2(17)$ \\
\hline & 7 & 日本図学会九州支部設立 & \\
\hline & 8 & 第 15 回例会（東北支部と合同）（於 花卷市） & \\
\hline & 9 & 10 周年記念事業案の検討始まる & \\
\hline & 12 & 『図形処理便覧』(のちに『図形科学ハンドブック』と改称) 出版準備委員会発足 & \\
\hline
\end{tabular}




\begin{tabular}{|c|c|c|c|}
\hline 年 & 月 & & $\begin{array}{l}\text { 巻-号 } \\
\text { (通号) }\end{array}$ \\
\hline \multirow[t]{4}{*}{$\begin{array}{l}1976 \\
(\mathrm{~S} .51)\end{array}$} & 5 & $\begin{array}{l}\text { 日本図学会 } 1976 \text { 年度大会開催（於 九州大学） } \\
\text { 会員数 } 209 \text { 名, 会費值上げ, 創立 } 10 \text { 周年記念事業の準備を開始 } \\
\text { 特別講演「九州の石仏について」(谷口鉄雄) }\end{array}$ & $10-2(19)$ \\
\hline & 8 & $\begin{array}{l}\text { 合同例会 }(\text { 本部・東海地区・関西支部) (於 京都大学 }) \\
\text { 特別講演「群衆歩行のシミュレーション」(岡崎甚幸) }\end{array}$ & \\
\hline & 10 & 創立 10 周年記念事業後援会発足 & \\
\hline & 12 & 創立 10 周年記念事業募金計画案承認 & \\
\hline \multirow[t]{2}{*}{$\begin{array}{l}1977 \\
\text { (S.52) }\end{array}$} & 5 & $\begin{array}{l}\text { 日本図学会 } 1977 \text { 年度・創立 } 10 \text { 周年記念大会開催（於 東京大学） } \\
\text { 会員数 } 205 \text { 名, 役員改選 (会長 : 熊谷貞男), } \\
\text { 〈日本図学会創立 } 10 \text { 周年記念事業後援会〉募金報告, 罒学ライブラリ規定決定, 便覧刊行委 } \\
\text { 員会報告, 用語委員会『図学用語集』をもって本年限りで解散と決定. } \\
\text { 記念講演「古代アメリカの都市と建築」(増田昭三 }) \text { 「図学的コンピュータの話」(穂坂衛), } \\
\text { 懇談会「図学教育の電算機の導入をめぐって」 }\end{array}$ & $11-2(21)$ \\
\hline & 12 & 本部例会（凸版印刷見学） & \\
\hline \multirow{5}{*}{$\begin{array}{l}1978 \\
(\mathrm{~S} .53)\end{array}$} & 4 & 会報 42 号に図学ライブラリ寄贈図書（1977 年 5 月〜 1978 年 3 月）リスト掲載 & \\
\hline & 5 & $\begin{array}{l}\text { 日本図学会 } 1978 \text { 年度大会開催（於 名古屋大学） } \\
\text { 会員数 } 208 \text { 名, 創立 } 10 \text { 周年記念事業後援会決算報告, 『図形処理便覧』の名称を『図形科学 } \\
\text { ハンドブック』に最終決定 } \\
\text { 記念講演「城はどうして作られたか」(内藤昌) }\end{array}$ & $12-2(23)$ \\
\hline & 6 & $\begin{array}{l}\text { 米国工学教育協会（ASEE）の機械設計製図部会 EDGD が創立 } 50 \text { 周年を記念してカナダの } \\
\text { バンクーバーにて図学国際会議（International Conference on Descriptive Geometry）開催, } \\
\text { 日本より } 3 \text { 論文発表，4名参加 }\end{array}$ & $13-1(24)$ \\
\hline & 9 & 学会 PR 版 & \\
\hline & 12 & 本部例会（小西六写真工業見学） & \\
\hline \multirow[t]{5}{*}{$\begin{array}{l}1979 \\
\text { (S.54) }\end{array}$} & 2 & $\begin{array}{l}\text { 会報 } 45 \text { 号から「文珠独語」欄が設けられる } \\
\text { 開設執筆は「図学の危機」(上田益造), 題字は熊谷貞夫会長.「文珠」は近代図学の祖 G. } \\
\text { Monge に因んだもの，挿絵は Mongeの “Géométrie descriptive”より掲載. }\end{array}$ & \\
\hline & 3 & $\begin{array}{l}\text { 国立国会図書館逐次刊行物部から『図学研究』に対し，ISSN（International Standard Serial } \\
\text { Number）0387-5512 を割り当てられる }\end{array}$ & \\
\hline & 5 & $\begin{array}{l}\text { 日本図学会 } 1979 \text { 年度大会開催（於 金沢大学） } \\
\text { 会員数 } 235 \text { 名, 役員改選（会長 : 小山清男), 文献調查委員会発足 } \\
\text { 特別講演「金沢の伝統文化」(嶋崎丞 })\end{array}$ & $13-2(25)$ \\
\hline & 10 & 『図学研究』投稿規定の改定 & \\
\hline & 11 & 本部例会（コンピュータ・グラフィックス委員会と合同）（日立精工，武藤工業見学） & \\
\hline
\end{tabular}




\begin{tabular}{|c|c|c|c|}
\hline 年 & 月 & & $\begin{array}{l}\text { 巻 }- \text { 号 } \\
\text { (通号) }\end{array}$ \\
\hline \multirow{6}{*}{$\begin{array}{l}1980 \\
(\mathrm{~S} .55)\end{array}$} & 2 & 名誉会員通知状・学会賞賞状作製（地模様：小山清男・鹿島享担当） & \\
\hline & 4 & 『図学研究』投稿規定内規決定 & \\
\hline & 5 & $\begin{array}{l}\text { 日本図学会 } 1980 \text { 年度大会開催（於 大阪大学） } \\
\text { 特別講演「大阪の史蹟一適塾とその周辺」(伴忠康) }\end{array}$ & $14-2(27)$ \\
\hline & 6 & 『図形科学ハンドブック』刊行 & \\
\hline & 9 & 学会賞賞状の印刷用原稿文字を熊谷貞男に依頼, 10 月完成 & \\
\hline & 12 & $\begin{array}{l}\text { 本部例会（於 東京藝術大学） } \\
\text { 特別講演「東大寺大仏の調査について」(前田泰次), 映画「幾何形態のアニメーション」 }\end{array}$ & \\
\hline \multirow[t]{3}{*}{$\begin{array}{l}1981 \\
(\mathrm{~S} .56)\end{array}$} & 5 & $\begin{array}{l}\text { 日本図学会 } 1981 \text { 年度大会開催（於 東京理科大学） } \\
\text { 会員数 } 246 \text { 名, 役員改選（会長：原正敏） }\end{array}$ & $15-2(29)$ \\
\hline & 7 & 会誌の規格を正規の B5 判に統一 & \\
\hline & 11 & 本部例会（朝日新聞本社見学） & \\
\hline \multirow{4}{*}{$\begin{array}{l}1982 \\
(\mathrm{~S} .57)\end{array}$} & 2 & 会報 57 号に図学ライブラリ寄贈図書（1978 年 4 月〜1981 年 10 月）リスト掲載 & \\
\hline & 5 & $\begin{array}{l}\text { 日本図学会 } 1982 \text { 年度大会開催（於 関西大学） } \\
\text { 会員数 } 244 \text { 名, 会費値上げ, 文献調査委員会がこれまでの調査結果を『図学研究』No. 27〜 } \\
30 \text { 号に掲載したと報告 }\end{array}$ & $16-2(31)$ \\
\hline & 7 & 『図学研究』に「図学ノート」設置を決定 & \\
\hline & & 本部見学会（東洋電機製造・武藤工業の両工場） & \\
\hline \multirow[t]{3}{*}{$\begin{array}{l}1983 \\
(\mathrm{~S} .58)\end{array}$} & 5 & $\begin{array}{l}\text { 日本図学会 } 1983 \text { 年度大会開催（於 千葉工業大学） } \\
\text { 役員改選（会長：磯田浩） }\end{array}$ & $17-2(33)$ \\
\hline & 10 & コンピュータ・グラフィックス教育懇談会開催 & $18-1(35)$ \\
\hline & 11 & 会報 64 号にコンピュータ・グラフィックスの図学教育への導入に関する調査結果を掲載 & \\
\hline \multirow{6}{*}{$\begin{array}{l}1984 \\
(\mathrm{~S} .59)\end{array}$} & 4 & 会報 66 号に図学ライブラリ寄贈図書（1981 年 11 月〜1983 年 3 月）リスト掲載 & \\
\hline & \multirow[t]{2}{*}{5} & $\begin{array}{l}\text { 日本図学会 } 1984 \text { 年度大会開催（於 大阪市立大学文化交流センター） } \\
\text { 会員数 } 345 \text { 名, コンピュータ・グラフィックス教育懇談会をコンピュータ・グラフィックス } \\
\text { 教育研究会に改組, 東海地区が支部設立準備を開始 }\end{array}$ & $18-2(35)$ \\
\hline & & $\begin{array}{l}\text { 第 } 2 \text { 回コンピュータ・グラフィックス教育研究会開催（以降, ほぼ毎年開催, } 1994 \text { 年からは } \\
\text { 年 } 2 \text { 回開催 })\end{array}$ & $18-2(35)$ \\
\hline & 8 & $\begin{array}{l}\text { 第 } 2 \text { 回図学国際会議 ICECG（International Conference on Engineering and Computer Graph- } \\
\text { ics）中華人民共和国北京にて開催（中国工程図学学会と米国工学教育学会機械製図部会の共 } \\
\text { 催), 日本より } 9 \text { 論文発表， } 23 \text { 名参加 }\end{array}$ & $19-1(36)$ \\
\hline & \multirow[t]{2}{*}{10} & 第 3 回コンピュータ・グラフィックス教育研究会開催 & \\
\hline & & $\begin{array}{l}\text { 本部例会（於 東京理科大学） } \\
\text { 特別講演「図学教育について」(幸田彰) }\end{array}$ & \\
\hline
\end{tabular}




\section{0 年の歩み}

\begin{tabular}{|c|c|c|c|}
\hline 年 & 月 & & $\begin{array}{l}\text { 巻 }- \text { 号 } \\
\text { (通号) }\end{array}$ \\
\hline \multirow{9}{*}{$\begin{array}{l}1985 \\
(\mathrm{~S} .60)\end{array}$} & 1 & 20 周年記念事業準備委員会発足（5 月に委員決定）（委員長：磯田浩） & \\
\hline & \multirow[t]{2}{*}{5} & $\begin{array}{l}\text { 日本図学会 } 1985 \text { 年度大会開催（於 青山学院大学） } \\
\text { 研究発表が } 2 \text { 会場になる, 役員改選（会長 : 小高司郎) }\end{array}$ & 19-2(37) \\
\hline & & 第 4 回コンピュータ・グラフィックス教育研究会 & \\
\hline & \multirow[t]{2}{*}{9} & 第 1 回 GST 研究会 & \\
\hline & & 本部例会をコンピュータ・グラフィックス教育研究会と合同で開催 & \\
\hline & \multirow[t]{2}{*}{11} & 20 周年記念事業案提出 & \\
\hline & & 日本図学会中部支部設立（東海地区より）（於 名古屋大学） & \\
\hline & \multirow[t]{2}{*}{12} & 会則・編集などの作業部会設置 & \\
\hline & & 第 2 回 GST 研究会 & \\
\hline \multirow{14}{*}{$\begin{array}{l}1986 \\
(\mathrm{~S} .61)\end{array}$} & 1 & 作業部会報告 & \\
\hline & 3 & 大会発表予稿集の形式を統一 & \\
\hline & \multirow[t]{2}{*}{4} & 第 3 回 GST 研究会 & \\
\hline & & 学生会員制設置 & \\
\hline & \multirow[t]{2}{*}{5} & $\begin{array}{l}\text { 日本図学会 } 1986 \text { 年度大会開催（於 九州大学） } \\
\text { 会費值上, 創立 } 20 \text { 周年記念事業案承認〈『図学研究』記念号発行, 記念出版『図形科学ハン } \\
\text { ドブックーコンピュータ編 (仮)』, 記念募金〉, } \\
\text { 将来構想委員会発足 }\end{array}$ & $20-2(39)$ \\
\hline & & 第 6 回コンピュータ・グラフィックス教育研究会 & \\
\hline & 9 & 第 5 回 GST 研究会 & \\
\hline & \multirow[t]{7}{*}{11} & 日本図学会北海道地区（連絡会）設立 & \\
\hline & & 記念誌『日本図学会創立 20 周年の歩み』(『罒学研究』記念号) 発行を内定 & \\
\hline & & 本部例会（於 東京工業大学） & \\
\hline & & 将来構想委員会 初会合 & \\
\hline & & 第 7 回コンピュータ・グラフィックス教育研究会 & \\
\hline & & 会報 76 号より投稿欄「図学ミニ」設置 & \\
\hline & & 第 6 回 GST 研究会 & \\
\hline \multirow{3}{*}{$\begin{array}{l}1987 \\
(\mathrm{~S} .62)\end{array}$} & 1 & 20 周年記念事業の準備が順調に進む & \\
\hline & 2 & $\begin{array}{l}1986 \text { 年度文部省科学研究補助金総合（B）「図学教育へのコンピュータグラフィックスの導 } \\
\text { 入法に関する研究」(研究代表者：永野三郎）により，さまざまな大学の教育害施例をまと } \\
\text { めた報告書を作成 }\end{array}$ & $\begin{array}{l}21 \\
\text { (記念号) }\end{array}$ \\
\hline & 3 & 『図学研究』第 40 号から年 3 回 (3 月, 8 月, 12 月) 刊行 & $21-1(40)$ \\
\hline
\end{tabular}




\begin{tabular}{|c|c|c|c|}
\hline 年 & 月 & & $\begin{array}{l}\text { 巻 }- \text { 号 } \\
\text { (通号) }\end{array}$ \\
\hline \multirow[t]{9}{*}{$\begin{array}{l}1987 \\
(\mathrm{~S} .62)\end{array}$} & \multirow[t]{2}{*}{5} & $\begin{array}{l}\text { 日本図学会 } 1987 \text { 年度・創立 } 20 \text { 周年記念大会（於 東京大学） } \\
\text { 会員数 } 265 \text { 名, 役員改選 (会長 : 岩井実), 記念式典 } \\
\text { 記念講演「CAD 教育の現状と将来」(中島尚正), パネル討論「今後の図学教育」(鈴木賢次 } \\
\text { 郎・田中喬・広部達也), 学術講演 } 28 \text { 件 }\end{array}$ & $21-2(41)$ \\
\hline & & 『図学研究』 20 周年記念号『日本図学会創立 20 年の歩み』刊行（委員長 : 喜山宜志明） & \\
\hline & 6 & 第 7 回 GST 研究会 & \\
\hline & 8 & 第 8 回 GST 研究会 & \\
\hline & 9 & 『図学研究』投稿規定改定の検討始まる & \\
\hline & \multirow[t]{2}{*}{10} & $\begin{array}{l}\text { 創立 } 20 \text { 周年記念募金の決算報告 } \\
\text { (後援会会長 : 牧博司, 寄付金総額 } 2,449,000 \text { 円) }\end{array}$ & \\
\hline & & 第 9 回 GST 研究会 & \\
\hline & \multirow[t]{2}{*}{12} & 本部例会（於 千葉工業大学） & \\
\hline & & 第 8 回コンピュータ・グラフィックス教育研究会 & $22-1(43)$ \\
\hline \multirow{10}{*}{$\begin{array}{l}1988 \\
\text { (S.63) }\end{array}$} & \multirow[t]{2}{*}{3} & 罒学国際会議の日本開催についての議論始まる & \\
\hline & & 第 10 回 GST 研究会 & \\
\hline & 5 & $\begin{array}{l}\text { 日本図学会 } 1988 \text { 年度大会（於 東北大学） } \\
\text { 会員数 } 284 \text { 名, 『図学研究』投稿規定は改定案原案通り承認 } \\
\text { 記念講演「伊達家」(伊達篤郎), 特別講演「中国の図学事情」(楊鈡藩), 学術講演 } 14 \text { 件 }\end{array}$ & $22-2(44)$ \\
\hline & 7 & $\begin{array}{l}\text { 第 } 3 \text { 回図学国際会議 ICEGDG（International Conference on Engineering Graphics and De- } \\
\text { scriptive Geometry）オーストリア国ウィーンにて開催，日本より } 16 \text { 論文発表，26名参加 }\end{array}$ & $22-3(45)$ \\
\hline & \multirow[t]{3}{*}{8} & $\begin{array}{l}\text { 日本図学会北海道支部設立（支部設立総会（於 北海道大学 }) \text { ) } \\
\text { (北海道地区（連絡会）より支部へ) }\end{array}$ & \\
\hline & & 本部見学会（大日本印刷（株）市ヶ谷工場） & \\
\hline & & 第 11 回 GST 研究会 & \\
\hline & 11 & 第 12 回 GST 研究会 & \\
\hline & \multirow[t]{2}{*}{12} & 第 9 回コンピュータ・グラフィックス教育研究会 & $23-1(46)$ \\
\hline & & 本部例会（於 明星大学） & \\
\hline \multirow{5}{*}{$\begin{array}{l}1989 \\
\text { (H.元) }\end{array}$} & 3 & 第 13 回 GST 研究会 & \\
\hline & \multirow[t]{4}{*}{5} & $\begin{array}{l}\text { 日本図学会 } 1989 \text { 年度大会（於 東京工業大学） } \\
\text { 学術講演 } 18 \text { 件, 会員数 } 299 \text { 名, 役員改選（会長 : 竹山和彦） }\end{array}$ & $23-2(47)$ \\
\hline & & 国際会議連絡委員会新設 & \\
\hline & & 20 周年記念出版『CG ハンドブック』刊行（委員長：磯田浩） & \\
\hline & & 第 10 回コンピュータ・グラフィックス教育研究会 & $23-2(47)$ \\
\hline
\end{tabular}




\begin{tabular}{|c|c|c|c|}
\hline 年 & 月 & & $\begin{array}{l}\text { 巻 }- \text { 号 } \\
\text { (通号) }\end{array}$ \\
\hline \multirow{7}{*}{$\begin{array}{l}1989 \\
\text { (H.元) }\end{array}$} & 6 & 第 14 回 GST 研究会 & \\
\hline & 7 & 会則改正の検討始まる & \\
\hline & 8 & 第 15 回 GST 研究会 & \\
\hline & 9 & 九州支部第 1 回図学教育シンポジウム & $24-2(50)$ \\
\hline & \multirow[t]{3}{*}{12} & 本部例会（於 東京芸術大学） & \\
\hline & & 本部見学会（NHK） & \\
\hline & & 第 16 回 GST 研究会 & \\
\hline \multirow{9}{*}{$\begin{array}{l}1990 \\
(\mathrm{H} .2)\end{array}$} & 3 & 第 17 回 GST 研究会 & \\
\hline & 6 & $\begin{array}{l}\text { 第 } 4 \text { 回図学国際会議 ICECGDG（International Conference on Engineering Computer Graphics } \\
\text { and Descriptive Geometry）米国マイアミにて開催，日本より } 16 \text { 論文発表，30 名参加 }\end{array}$ & $24-2(50)$ \\
\hline & \multirow[t]{2}{*}{7} & 第 11 回コンピュータ・グラフィックス教育研究会 & $24-2(50)$ \\
\hline & & $\begin{array}{l}\text { 日本図学会 } 1990 \text { 年度大会 }(\text { 於 北海道大学) } \\
\text { 会員数 } 293 \text { 名, 会則改正は原案通り承認 } \\
\text { 学術講演 } 24 \text { 件 }\end{array}$ & $24-2(50)$ \\
\hline & 9 & $\begin{array}{l}\text { 会則改正により役員会を理事会と改称 } \\
\text { 会則改正にともなう学会賞受賞規定・図学ライブラリー規定などの改定の検討始まる }\end{array}$ & \\
\hline & 10 & 九州支部第 2 回図学教育シンポジウム「昭和期の図学教育」 & $\begin{array}{l}25-2(53), \\
31-1(75)\end{array}$ \\
\hline & \multirow[t]{3}{*}{12} & 本部例会（於 防衛大学校） & \\
\hline & & 大会学術講演論文集の簡易印刷の検討始まる & \\
\hline & & 第 18 回 GST 研究会 & \\
\hline \multirow{8}{*}{$\begin{array}{l}1991 \\
\text { (H.3) }\end{array}$} & 1 & 大会学術講演論文集の簡易印刷決定 & \\
\hline & 3 & 第 19 回 GST 研究会 & \\
\hline & 5 & $\begin{array}{l}\text { 日本図学会 } 1991 \text { 年度大会（於 東京理科大学） } \\
\text { 会員数 } 307 \text { 名, 役員改選 (会長 : 竹山和彦) } \\
\text { シンポジウム「今後の図学教育にむけて一学会は何をなすべきか一」(永野三郎・川北和明・ } \\
\text { 柴田優・鈴木賢次郎), 学術講演 } 24 \text { 件 }\end{array}$ & $\begin{array}{l}25^{-2}(53) \\
25^{-}-2(53)\end{array}$ \\
\hline & 6 & 第 20 回 GST 研究会 & \\
\hline & \multirow[t]{3}{*}{8} & $\begin{array}{l}\text { 竹山和彦会長・鈴木賢次郎理事, 中国工程図学学会の招待により CADDM '91 に参加し, 工 } \\
\text { 程図学学会と教育研究会議の開催について協議. }\end{array}$ & $25^{-}-3(54)$ \\
\hline & & 第 21 回 GST 研究会 & \\
\hline & & 第 1 回パソコン利用研究会 & \\
\hline & 9 & $\begin{array}{l}\text { 中国工程図学学会と主催する日中図学教育研究会の開催は’ } 93 \text { 年 } 3 \text { 月（中国）と決定し, 準 } \\
\text { 備作業を始める }\end{array}$ & \\
\hline
\end{tabular}




\begin{tabular}{|c|c|c|c|}
\hline 年 & 月 & & $\begin{array}{l}\text { 巻 }- \text { 号 } \\
\text { (通号) }\end{array}$ \\
\hline \multirow{3}{*}{$\begin{array}{l}1991 \\
\text { (H.3) }\end{array}$} & \multirow[t]{2}{*}{10} & 本部例会（於 山梨県立宝石美術専門学校） & \\
\hline & & 罒学国際会議 ICECGDG の ’94 年日本開催の準備作業を始める & \\
\hline & 11 & 九州支部第 3 回図学教育シンポジウム「明治期の図学教育」 & $31-1(75)$ \\
\hline \multirow{18}{*}{$\begin{array}{l}1992 \\
\text { (H.4) }\end{array}$} & 2 & 日中図学教育研究会の正式名称を「日中図学教育研究国際会議」と決定 & \\
\hline & \multirow[t]{2}{*}{3} & 「日中図学教育研究国際会議」の ’93 年 3 月開催の会告 & \\
\hline & & 『図学研究』第 55 号から年 4 回 (3 月, 6 月, 9 月, 12 月) 刊行, 会報の発行を取りやめ & $26-1(55)$ \\
\hline & 4 & 第 22 回 GST 研究会 & \\
\hline & \multirow[t]{3}{*}{5} & $\begin{array}{l}\text { 日本図学会 } 1992 \text { 年度大会 (於 中部大学) } \\
\text { 会員数 } 317 \text { 名 } \\
\text { シンポジウム「形状と造形感覚一図学の萌芽的研究一」(堤浪夫), 学術講演 } 26 \text { 件 }\end{array}$ & $26-3(57)$ \\
\hline & & $\begin{array}{l}\text { 第 } 12 \text { 回コンピュータ・グラフィックス教育研究会（日中図学教育研究国際会議開催にむけ } \\
\text { て） }\end{array}$ & $26-3(57)$ \\
\hline & & 第 23 回 GST 研究会 & \\
\hline & 6 & 第 24 回 GST 研究会 & \\
\hline & 7 & 第 25 回 GST 研究会 & \\
\hline & \multirow[t]{3}{*}{8} & $\begin{array}{l}\text { 第 } 5 \text { 回図学国際会議 ICECGDG メルボルンにて開催，日本より } 23 \text { 論文発表，34 名参加，’94 } \\
\text { 年の東京開催決定 }\end{array}$ & $26-3(57)$ \\
\hline & & 国際図学会（International Society for Geometry and Graphics）設立 & \\
\hline & & 第 2 回パソコン利用研究会 & \\
\hline & 9 & 第 26 回 GST 研究会 & \\
\hline & \multirow[t]{5}{*}{11} & 本部見学会（日本航空（株）フライトシミュレーションセンター） & \\
\hline & & 本部例会（於 大妻女子大学） & \\
\hline & & 罒学国際会議組織委員会（委員長 : 永野三郎) ·実行委員会（委員長 : 鈴木賢次郎）発足 & \\
\hline & & 第 27 回 GST 研究会 & \\
\hline & & 九州支部第 4 回図学教育シンポジウム「義務教育における図形教育」 & $31-1(75)$ \\
\hline \multirow[t]{3}{*}{$\begin{array}{l}1993 \\
\text { (H.5) }\end{array}$} & \multirow[t]{2}{*}{3} & $\begin{array}{l}\text { 第 } 1 \text { 回日中図学教育研究国際会議（Japan-China Joint International Conference on Graphics } \\
\text { Education）無錫にて開催，日本より } 31 \text { 論文発表，37 名参加 }\end{array}$ & $27-2(60)$ \\
\hline & & 図学国際会議東京大会のファーストサーキュラー送付 & \\
\hline & 5 & $\begin{array}{l}\text { 日本図学会 } 1993 \text { 年度大会（於 武蔵野美術大学） } \\
\text { 会員数 } 330 \text { 名, 役員改選 (会長 : 堤浪夫), コンピュータ・グラフィックス教育研究会を図 } \\
\text { 学教育研究会に改組 } \\
\text { シンポジウム「美術・造形にとって図学とは」(鹿島享・源田悦夫・佐久間義敬・村松俊夫・ } \\
\text { 面出和子), 学術講演 } 22 \text { 件 }\end{array}$ & $\begin{array}{l}27-2(60), \\
27-3(61)\end{array}$ \\
\hline
\end{tabular}




\section{0 年の歩み}

\begin{tabular}{|c|c|c|c|}
\hline 年 & 月 & & $\begin{array}{l}\text { 巻 - 号 } \\
\text { (通号) }\end{array}$ \\
\hline \multirow{10}{*}{$\begin{array}{l}1993 \\
(\mathrm{H} .5)\end{array}$} & \multirow[t]{2}{*}{6} & 図学国際会議 ICECGDG 東京大会の会告 & \\
\hline & & 第 28 回 GST 研究会 & \\
\hline & 7 & 第 29 回 GST 研究会 & \\
\hline & \multirow[t]{3}{*}{8} & CAD/CAM セミナー（於 摂南大学） & $27-4(62)$ \\
\hline & & 第 3 回パソコン利用研究会 & $27-4(62)$ \\
\hline & & 第 30 回 GST 研究会 & \\
\hline & 10 & $\begin{array}{l}\text { 九州支部第 } 5 \text { 回図学教育シンポジウム・第 } 13 \text { 回図学教育研究会（共催） } \\
\text { 「海外における図学教育」 }\end{array}$ & $\begin{array}{l}28-1(63), \\
31-1(75)\end{array}$ \\
\hline & \multirow[t]{3}{*}{11} & 本部例会（於 女子美術大学） & \\
\hline & & 本部見学会（(株) フェイズ） & \\
\hline & & 第 31 回 GST 研究会 & \\
\hline \multirow{11}{*}{$\begin{array}{l}1994 \\
(\mathrm{H} .6)\end{array}$} & 2 & 罒学国際会議東京大会のファーストサーキュラー送付, 準備順調に進む & \\
\hline & \multirow[t]{2}{*}{6} & 中国工程図学学会から第 2 回日中図学研究国際会議開催の打診 & \\
\hline & & 第 32 回 GST 研究会 & \\
\hline & 7 & 第 33 回 GST 研究会 & \\
\hline & \multirow[t]{3}{*}{8} & 第 4 回パソコン利用研究会 & \\
\hline & & $\begin{array}{l}\text { 日本図学会 } 1994 \text { 年度総会（於 大妻女子大学） } \\
\text { 会員数 } 330 \text { 名 }\end{array}$ & $28-3(65)$ \\
\hline & & $\begin{array}{l}\text { 第 } 6 \text { 回図学国際会議 ICECGDG 東京（大妻女子大学）にて開催，日本より } 82 \text { 論文発表，146 } \\
\text { 名参加，会議参加登録者 } 214 \text { 名（ロゴマークデザイン：佐々木仁） }\end{array}$ & $28-4(66)$ \\
\hline & 11 & $\begin{array}{l}\text { 九州支部第 } 6 \text { 回図学教育シンポジウム・第 } 14 \text { 回図学教育研究会（共催） } \\
\text { 「清家正の思想」 }\end{array}$ & $\begin{array}{l}29-1(67), \\
31-1(75)\end{array}$ \\
\hline & \multirow[t]{3}{*}{12} & 本部例会（於 武蔵工業大学） & \\
\hline & & 第 15 回図学教育研究会「図学教育の現状と将来(1)」 & $29-1(67)$ \\
\hline & & 第 34 回 GST 研究会 & \\
\hline \multirow{5}{*}{$\begin{array}{l}1995 \\
(\mathrm{H} .7)\end{array}$} & \multirow[t]{2}{*}{3} & 第 2 回日中図学研究国際会議の開催決定 & \\
\hline & & 第 35 回 GST 研究会 & \\
\hline & \multirow[t]{2}{*}{5} & $\begin{array}{l}\text { 日本図学会 } 1995 \text { 年度大会 (於 大阪電気通信大学) } \\
\text { 会員数 } 341 \text { 名, 役員改選 (会長 : 永野三郎) } \\
\text { 記念講演「阪神・淡路大震災と免震構造」(橘英三郎), 学術講演 } 25 \text { 件 }\end{array}$ & $29-2(68)$ \\
\hline & & 第 16 回図学教育研究会「図学教育の現状と将来 (2)」 & $29-3(69)$ \\
\hline & 6 & 学会創立 30 周年記念事業の検討開始 & \\
\hline
\end{tabular}




\begin{tabular}{|c|c|c|c|}
\hline 年 & 月 & & $\begin{array}{l}\text { 巻 }- \text { 号 } \\
\text { (通号) }\end{array}$ \\
\hline \multirow{8}{*}{$\begin{array}{l}1995 \\
(\mathrm{H} .7)\end{array}$} & \multirow[t]{2}{*}{6} & 電子化情報検討委員会の設置決まる & \\
\hline & & 第 36 回 GST 研究会 & \\
\hline & 7 & 第 37 回 GST 研究会 & \\
\hline & \multirow[t]{2}{*}{9} & $\begin{array}{l}\text { 第 } 2 \text { 回日中図学教育研究国際会議（Japan-China Joint Conference on Graphics Education）成 } \\
\text { 都にて開催, 日本より } 20 \text { 論文発表, } 37 \text { 名参加 }\end{array}$ & $29-4(70)$ \\
\hline & & 第 38 回 GST 研究会 & \\
\hline & 11 & 第 39 回 GST 研究会 & \\
\hline & \multirow[t]{2}{*}{12} & 第 17 回図学教育研究会「図学教育の現状と将来(3)一隣接分野からの提言一」 & $30-2(72)$ \\
\hline & & 本部例会（於 東海大学短期大学部） & \\
\hline \multirow[t]{10}{*}{$\begin{array}{l}1996 \\
(\mathrm{H} .8)\end{array}$} & \multirow[t]{2}{*}{5} & $\begin{array}{l}\text { 日本図学会 } 1996 \text { 年度大会（於 九州大学） } \\
\text { 会員数 } 359 \text { 名, } 30 \text { 周年記念事業計画案承認（記念大会の開催・記念出版事業 [『図学研究』 } \\
30 \text { 周年記念号・『マルチメディア・コミュニーーション』・美の図学』・『四学用語集〈仮 } \\
\text { 称〉』]・記念表彰 [論文賞・奨励賞・教育功労賞・教育奨励賞・学会功労賞など }])\end{array}$ & $30-2(72)$ \\
\hline & & 第 18 回図学教育研究会「図学教育の現状と将来 (4)」 & $30-3(73)$ \\
\hline & \multirow[t]{2}{*}{7} & $\begin{array}{l}\text { 第 } 7 \text { 回図学国際会議 ICECGDG ポーランド国クラコフにて開催, 日本より } 28 \text { 論文発表, } 42 \\
\text { 名参加, この会議より日本図学会は図学国際会議の共催として, 会議開催に協力することに } \\
\text { なった }\end{array}$ & $31-2(76)$ \\
\hline & & 第 40 回 GST 研究会 & \\
\hline & \multirow[t]{3}{*}{9} & 電子化情報検討委員会の調査報告 & $30-3(73)$ \\
\hline & & 九州支部第 7 回図学教育シンポジウム「図形教育シンポジウムをふり返って」 & $31-1(75)$ \\
\hline & & 第 41 回 GST 研究会 & \\
\hline & 11 & 本部例会（於 青山学院大学） & \\
\hline & \multirow[t]{2}{*}{12} & $\begin{array}{l}\text { 第 } 19 \text { 回図学教育研究会「図学教育の現状と将来 }(5) \text { 一米・豪における（機械系）図学関連教 } \\
\text { 育一」 }\end{array}$ & $31-2(76)$ \\
\hline & & 30 周年記念大会の準備作業順調に進む & \\
\hline \multirow{4}{*}{$\begin{array}{l}1997 \\
(\mathrm{H} .9)\end{array}$} & 1 & 第 42 回 GST 研究会（於 三菱重工業株式会社神戸造船所）, 講演 2 件 & \\
\hline & \multirow[t]{2}{*}{4} & 『図学研究』30 周年記念号『四学は今』刊行 (委員長 : 堤江美子) & \\
\hline & & $\begin{array}{l}30 \text { 周年記念出版 『シンセティック } \mathrm{CAD} \text { 一コンピュータ支援による設計製図の実際』刊行 } \\
\text { (委員長 : 鈴木賢次郎) }\end{array}$ & \\
\hline & 5 & $\begin{array}{l}\text { 日本図学会 } 1997 \text { 年度・創立 } 30 \text { 周年記念大会（於 東京大学） } \\
\text { 会員数 } 364 \text { 名, 役員改選 (会長 : 永野三郎), 記念式典, 記念表彰（論文賞, 奨励賞, 教育 } \\
\text { 功労賞, 教育奨励賞, 学会功労賞など), 賛助会員感謝状贈呈, 募金募集 } \\
\text { 〜次頁へ 記念大会つづく〜 }\end{array}$ & $31-2(77)$ \\
\hline
\end{tabular}




\begin{tabular}{|c|c|c|c|}
\hline 年 & 月 & & $\begin{array}{l}\text { 巻 }- \text { 号 } \\
\text { (通号) }\end{array}$ \\
\hline \multirow[t]{7}{*}{$\begin{array}{l}1997 \\
\text { (H.9) }\end{array}$} & 5 & $\begin{array}{l}\text { ～前頁から 記念大会つづく〜 } \\
\text { 記念講演「エンジニアリング・デザイン・グラフィックス・カリキュラムの現代化」（Davor } \\
\text { Juricic） } \\
\text { Dennis Short 教授 (Purdue 大学) 挨挳 } \\
\text { シンボジウム「図学の基礎領域とその展開」(井野智・鈴木賢次郎・D. Short・長江貞彦・面 } \\
\text { 出和子), 学術講演 } 39 \text { 件 }\end{array}$ & $31-3(77)$ \\
\hline & 5 & 30 周年記念出版『マルチメディア・コミュニケーション』刊行 (委員長 : 長江貞彦) & \\
\hline & 7 & $\begin{array}{l}\text { 第 } 3 \text { 回日中図学教育研究国際会議 昆明にて開催（於 見明工科大学）, 日本より } 27 \text { 論文発表, } \\
40 \text { 名参加 }\end{array}$ & $31-4(78)$ \\
\hline & 10 & 国際図学会論文誌 JGG（Journal for Geometry and Graphics）創刊号刊行 & \\
\hline & \multirow[t]{3}{*}{11} & 第 43 回 GST 研究会（於 牛空研修センター「カリヨンハウス」), 講演 2 件 & \\
\hline & & 本部例会 (於 日本大学生産工学部), 講演 10 件 & \\
\hline & & 第 20 回図学教育研究会「半年の一般（教養）図学」 & $32-1(79)$ \\
\hline \multirow{9}{*}{$\begin{array}{l}1998 \\
\text { (H.10) }\end{array}$} & 1 & 第 44 回 GST 研究会（於 山野酒造株式会社）, 講演 1 件 & \\
\hline & \multirow[t]{2}{*}{5} & $\begin{array}{l}\text { 日本図学会 } 1998 \text { 年度大会 }(\text { 於 北海道大学 }) \\
\text { 会員数 } 351 \text { 名, 記念講演「人と図形」(東弘孝), 学術講演 } 30 \text { 件 }\end{array}$ & $32-2(80)$ \\
\hline & & 第 21 回図学教育研究会「機械系図学関連教育」, 講演 5 件 & $32-3(81)$ \\
\hline & 6 & 30 周年記念出版『美の図学』刊行（委員長 : 小山清男） & \\
\hline & 7 & $\begin{array}{l}\text { 第 } 8 \text { 回図学国際会議 ICECGDG 米国テキサス州オースティンにて開催（於 テキサス大学), } \\
\text { この会議で国際図学会（ISGG）を正式主催団体として認証．発表論文 } 117 \text { 編，日本より } 28 \\
\text { 論文発表，56 名参加 }\end{array}$ & $32-4(82)$ \\
\hline & \multirow[t]{2}{*}{9} & $\begin{array}{l}\text { 日本図学会のロゴマークおよびロゴタイプを策定，1994 年図学国際会議のロゴ（作成：佐々 } \\
\text { 木仁）に改変を施す許可を得て作成（丸山剛） }\end{array}$ & \\
\hline & & 第 45 回 GST 研究会（於 大阪電気通信大学） & \\
\hline & \multirow[t]{2}{*}{11} & 本部例会 (於 埼玉大学), 講演 11 件 & \\
\hline & & 第 22 回図学教育研究会「造形芸術 - 被服系図学関連教育」, 講演 5 件 & $33-2(84)$ \\
\hline \multirow{5}{*}{$\begin{array}{l}1999 \\
(\mathrm{H} .11)\end{array}$} & 1 & 『図学研究』の投稿規定を改定 & \\
\hline & \multirow[t]{2}{*}{3} & $\begin{array}{l}\text { 『図学研究』の装丁が変わり（A4 サイズ化，表紙・レイアウトを一新，デザイン：丸山剛), } \\
\text { 内容の一層の充実が図られる }\end{array}$ & $33-1(83)$ \\
\hline & & 第 46 回 GST 研究会（於 明星金属工業 K.K.） & \\
\hline & \multirow[t]{2}{*}{5} & $\begin{array}{l}\text { 日本図学会 } 1999 \text { 年度大会（於 武蔵工業大学） } \\
\text { この回より大会開催期間を } 2 \text { 日間に変更 } \\
\text { 会員数 } 351 \text { 名, 役員改選 (会長 : 吉田勝行), 学生会員の新設, 会費改定が承認される, 学 } \\
\text { 術講演 } 32 \text { 件 }\end{array}$ & $33-2(84)$ \\
\hline & & 第 23 回図学教育研究会「CG 図学」, 講演 5 件 & $33-3(85)$ \\
\hline
\end{tabular}




\begin{tabular}{|c|c|c|c|}
\hline 年 & 月 & & $\begin{array}{l}\text { 巻 - 号 } \\
\text { (通号) }\end{array}$ \\
\hline \multirow[t]{5}{*}{$\begin{array}{l}1999 \\
\text { (H.11) }\end{array}$} & 7 & $\begin{array}{l}\text { 第 } 4 \text { 回日中図学教育研究国際会議 敦煌にて開催，招待講演 } 5 \text { 編，発表論文 } 46 \text { 編，日本より } \\
28 \text { 論文発表，36 名参加 }\end{array}$ & $33-4(86)$ \\
\hline & 9 & 第 47 回 GST 研究会（於 大阪電気通信大学） & \\
\hline & 10 & 事務処理効率化のための会員番号導入 & \\
\hline & \multirow[t]{2}{*}{11} & 本部例会（於 東京工科大学), 講演 6 件 & \\
\hline & & 第 24 回図学教育研究会「設計にとって図学は必要か」, 講演 2 件 & $34-1(87)$ \\
\hline \multirow{11}{*}{$\begin{array}{l}2000 \\
\text { (H.12) }\end{array}$} & 2 & 学会作業全般の電子化の検討を開始 & \\
\hline & 3 & $\begin{array}{l}\text { 日本学術会議 } 50 \text { 周年記念シンポジウム「数学教育の改善をめざして」にて鈴木賢次郎・加 } \\
\text { 藤道夫が幾何学教育の必要性を意見する, 研究報告書「『総合的な学習の時間』の単元カリ } \\
\text { キュラムの開発と理論モデルの構築に関する研究」に「かたちを主題にした総合的学習の実 } \\
\text { 践」(小林範夫) }\end{array}$ & $\begin{array}{l}35-3(93) \\
37-4(102)\end{array}$ \\
\hline & 4 & 第 48 回 GST 研究会（於 大阪産業大学), 講演 2 編 & \\
\hline & \multirow[t]{4}{*}{5} & $\begin{array}{l}\text { 日本図学会 } 2000 \text { 年度大会（於 いわき明星大学） } \\
\text { 会員数 } 354 \text { 名, 日本図学会賞授賞規定を改定 } \\
\text { 特別講演「歴史教科書を変える最近の考古学的成果」(馬目順一), 学術講演 } 21 \text { 件 }\end{array}$ & $34-2(88)$ \\
\hline & & 学会活動および『図学研究』の電子化についてのアンケートを実施 & $34-4(90)$ \\
\hline & & 第 25 回図学教育研究会「設計と図学」, 講演 4 件 & \\
\hline & & 第 5 回日中図学教育研究国際会議（大阪）の準備を開始（組織委員長 : 吉田勝行） & \\
\hline & \multirow[t]{2}{*}{7} & 第 49 回 GST 研究会（於 関西文化サロン）, 講演 4 編 & \\
\hline & & $\begin{array}{l}\text { 第 } 9 \text { 回図学国際会議 ICGG（International Conference on Geometry and Graphics）南アフリカ } \\
\text { 共和国ヨハネスブルグにて開催，この回より主催は国際図学会 (ISGG). 招待講演 } 4 \text { 編, 発 } \\
\text { 表論文 } 73 \text { 編，会議参加登録者 } 92 \text { 名, 日本より } 32 \text { 論文発表, } 39 \text { 名参加 }\end{array}$ & $34-4(90)$ \\
\hline & \multirow[t]{2}{*}{11} & 本部例会（於 筑波技術短期大学), 研究発表 13 編 & \\
\hline & & 第 26 回図学教育研究会「専門科目としての CG 教育」, 講演 4 編 & $35^{-1}(91)$ \\
\hline \multirow[t]{6}{*}{$\begin{array}{l}2001 \\
\text { (H.13) }\end{array}$} & 3 & $\begin{array}{l}\text { 日本学術会議シンポジウム「21 世紀の多様性社会における基礎学力とは」において講演「図 } \\
\text { 学的表現ツールの進化と表現上の誤りの増加について」(吉田勝行) }\end{array}$ & $\begin{array}{l}35-3(93) \\
37-4(102)\end{array}$ \\
\hline & \multirow[t]{3}{*}{5} & ホームページデザインを変更 & \\
\hline & & $\begin{array}{l}\text { 日本図学会 } 2001 \text { 年度大会（於 青山学院大学） } \\
\text { 会員数 } 343 \text { 名, 役員改選 (会長 : 鈴木賢次郎) } \\
\text { 特別講演「知識進化図作成システム」(辻正重), 学術講演 } 27 \text { 件 }\end{array}$ & $35-2(92)$ \\
\hline & & 第 27 回図学教育研究会「専門科目としての CG 教育 $(2) 」$, 講演 4 編 & $35^{-3}(93)$ \\
\hline & \multirow[t]{2}{*}{6} & ホームページ改定・メーリングリストの設置など電子的環境の向上が図られる & \\
\hline & & 本部例会の大会化, 図学教育の現状調査などについて検討開始 & \\
\hline
\end{tabular}




\begin{tabular}{|c|c|c|c|}
\hline 年 & 月 & & $\begin{array}{l}\text { 巻 - 号 } \\
\text { (通号) }\end{array}$ \\
\hline \multirow[t]{4}{*}{$\begin{array}{l}2001 \\
(\mathrm{H} .13)\end{array}$} & $\begin{array}{l}7, \\
8\end{array}$ & $\begin{array}{l}\text { 第 } 5 \text { 回日中図学教育研究国際会議 大阪にて開催（於 大阪ガーデンパレス），参加者総数 } 97 \\
\text { 名，招待講演 } 4 \text { 編，発表論文 } 58 \text { 編，日本より } 44 \text { 論文発表，日本側参加者 } 73 \text { 名 }\end{array}$ & $\begin{array}{l}35-4(94), \\
36-1(95)\end{array}$ \\
\hline & 8 & $\begin{array}{l}\text { 日本学術会議科学教育研連フォーラム「日本の } 21 \text { 世紀半ばを想定した科学教育の体系化構 } \\
\text { 想」において講演「視覚化と図的思考をめぐって」(小高直樹) }\end{array}$ & $37-4(102)$ \\
\hline & \multirow[t]{2}{*}{12} & 本部例会（於 神奈川工科大学), 研究発表 8 編 & \\
\hline & & 第 28 回図学教育研究会「図学関連科目のシラパスと教材その $1 」$, 講演 2 編 & $36-1(95)$ \\
\hline \multirow{9}{*}{$\begin{array}{l}2002 \\
(\mathrm{H} .14)\end{array}$} & 2 & 名誉会員内規を制定 & $36-2(96)$ \\
\hline & \multirow[t]{2}{*}{5} & $\begin{array}{l}\text { 日本図学会 } 2002 \text { 年度大会（於 中部大学） } \\
\text { 会員数 } 343 \text { 名, 特別講演「生きるための動と静の戦略」(山下興要), 学術講演 } 31 \text { 件 }\end{array}$ & $36-2(96)$ \\
\hline & & 第 29 回図学教育研究会「図学関連科目のシラバス構築へむけて」 & $36-3(97)$ \\
\hline & $\begin{array}{l}7, \\
8\end{array}$ & $\begin{array}{l}\text { 第 } 10 \text { 回図学国際会議 ICGG ウクライナ共和国キエフにて開催，招待講演 } 4 \text { 編，発表論文 } 94 \\
\text { 編，日本より } 34 \text { 論文発表，38 名参加 }\end{array}$ & $36-4(98)$ \\
\hline & 9 & 日本技術者教育認定機構（JABEE）の正会員となる & \\
\hline & \multirow[t]{3}{*}{11} & 本部例会（於 文部省共催宿泊所静雲荘)，研究発表 14 編 & \\
\hline & & 第 30 回図学教育研究会「模型と展開図の活用」, 講演 9 編 & $37-1(99)$ \\
\hline & & $\begin{array}{l}\text { 困学および困的表現法の教育に関する実状調查を実施（臨時委員会 : 図学教育実状調查委員 } \\
\text { 会） }\end{array}$ & \\
\hline & 12 & $\begin{array}{l}\text { 日本学術会議シンポジウム「世界をリードするこれからの戦略的な科学技術教育の推進」に } \\
\text { おいて提案「科学技術者を支える指導者, 創造的研究者, 創造的技術者の育成」(加藤道夫) }\end{array}$ & $37-4(102)$ \\
\hline \multirow[t]{7}{*}{$\begin{array}{l}2003 \\
(\mathrm{H} .15)\end{array}$} & 2 & $\begin{array}{l}\text { 日本学術会議シンポジウム「21 世紀の市民の科学・技術リテラシーの体系化」において提案 } \\
\text { 「身近な美の理解を助ける図学とその教育」(近藤邦雄) }\end{array}$ & $37-4(102)$ \\
\hline & \multirow[t]{2}{*}{5} & $\begin{array}{l}\text { 日本図学会 } 2003 \text { 年度大会（於 女子美術大学） } \\
\text { 会員数 } 336 \text { 名, 役員改選（会長 : 鈴木賢次郎） } \\
\text { 女子美アートミュージアム・ギャラリートーク「具象と抽象のはざま」展（林敬二), 学術 } \\
\text { 講演 } 33 \text { 件 }\end{array}$ & $37-2(100)$ \\
\hline & & 第 31 回図学教育研究会「CAI システムおよび模型の活用」, 発表 8 編 & $37-3(101)$ \\
\hline & 6 & 『図学研究』通巻 100 号を発行（通巻 100 号特集） & $37-2(100)$ \\
\hline & 7 & $\begin{array}{l}\text { 第 } 6 \text { 回日中図学教育研究国際会議を西安で開催予定であったが，新型肺炎（SARS）流行のた } \\
\text { めWeb 会議にて開催 ; 第 } 6 \text { 回日中図学教育研究国際会議プロシーディングスを発行, 収録 } \\
\text { 論文 } 77 \text { 編 }\end{array}$ & \\
\hline & \multirow[t]{2}{*}{11} & 本部例会（於 熱海ニューフジヤホテル）, 研究発表 16 編 & $38-1(103)$ \\
\hline & & 第 32 回図学教育研究会「図学及び図的表現法の教育の現状と今後の展開」, 発表 2 編 & $38-1(103)$ \\
\hline \multirow{2}{*}{$\begin{array}{l}2004 \\
(\text { H.16) }\end{array}$} & 2 & 図学および図的表現法の教育に関する実状調査の結果まとまる & $39-1(107)$ \\
\hline & 5 & $\begin{array}{l}\text { 日本図学会 } 2004 \text { 年度大会（於 神戸大学） } \\
\text { 会員数 } 339 \text { 名, 特別講演「漢字の書法の変遷」(魚住和晃), 学術講演 } 43 \text { 件 }\end{array}$ & $38-2(104)$ \\
\hline
\end{tabular}




\begin{tabular}{|c|c|c|c|}
\hline 年 & 月 & & $\begin{array}{l}\text { 巻 }- \text { 号 } \\
\text { (通号) }\end{array}$ \\
\hline \multirow{5}{*}{$\begin{array}{l}2004 \\
\text { (H.16) }\end{array}$} & 5 & 第 33 回図学教育研究会「図学教材とその活用」 & $38-3(105)$ \\
\hline & 8 & $\begin{array}{l}\text { 第 } 11 \text { 回図学国際会議 ICGG 中華人民共和国広州にて開催，招待講演 } 4 \text { 編，発表論文 } 108 \text { 編, } \\
\text { 参加登録者 } 112 \text { 名，日本より } 34 \text { 論文発表，37 名参加 }\end{array}$ & $38-4(106)$ \\
\hline & \multirow[t]{2}{*}{12} & 本部例会（於 伊東パウエル）, 研究発表 14 編 & $39-1(107)$ \\
\hline & & 第 34 回図学教育研究会「CG/CAD ッールを利用した図学教育」, 講演 9 編 & $39-1(107)$ \\
\hline & 12 & $\begin{array}{l}\text { JABEE 国際シンポジウム「技術者教育とエンジニアリングデザイン」においてエンジニアリ } \\
\text { ングデザインの共通認識声明が出され，図表現が必要能力に含まれる }\end{array}$ & \\
\hline \multirow[t]{7}{*}{$\begin{array}{l}2005 \\
\text { (H.17) }\end{array}$} & 5 & 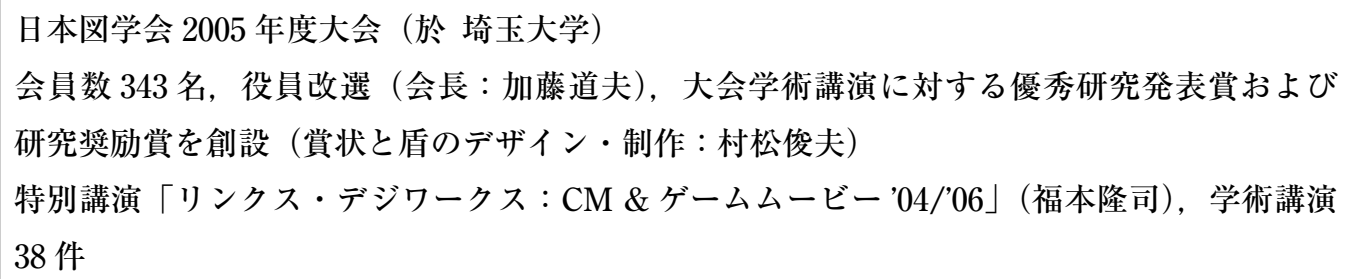 & $38-2(108)$ \\
\hline & & 第 35 回図学教育研究会「造形デザイン系の図学教育における教材とその教育実践」 & $39-3(109)$ \\
\hline & 6 & 『図学研究』の電子アーカイブ化を検討開始 & \\
\hline & 7 & $\begin{array}{l}\text { 第 } 7 \text { 回日中図学教育研究国際会議 西安にて開催, 発表論文 } 65 \text { 編, 日本より } 25 \text { 論文発表, } \\
26 \text { 名参加 }\end{array}$ & $\begin{array}{l}39-3(109), \\
39-4(110)\end{array}$ \\
\hline & 10 & 日本図学会, 日本学術会議の登録学術研究団体から協力学術研究団体 (第三部) へと移行 & \\
\hline & 12 & $\begin{array}{l}\text { 本部例会 (於 椇南大学), 特別講演「企業におけるデジタルエンジニアリングッールの活用」 } \\
\text { (宇土和宏),「図学／設計製図教育への } 3 \mathrm{D}-\mathrm{CAD} / \mathrm{CG} \text { 導入」(鈴木賢次郎), 研究発表 } 9 \text { 編 }\end{array}$ & $40-1(111)$ \\
\hline & & 第 36 回図学教育研究会「図学教育における透視図法の現状と今後」, 発表 12 編 & $40-1(111)$ \\
\hline \multirow{7}{*}{$\begin{array}{l}2006 \\
\text { (H.18) }\end{array}$} & 1 & 『図学研究』の PDF 化が完了 & \\
\hline & 4 & 企画委員会を設置 & \\
\hline & \multirow[t]{4}{*}{5} & $\begin{array}{l}\text { 日本図学会 } 2006 \text { 年度大会（於 九州産業大学） } \\
\text { 会員数 } 346 \text { 名 } \\
\text { 特別講演「シーボルトと絵師川原慶賀」(谷口治達), 学術講演 } 39 \text { 件 }\end{array}$ & $40-2(112)$ \\
\hline & & 第 37 回図学教育研究会「デジタルコンテンツ時代の図学教育」，発表 5 編 & $40-3(113)$ \\
\hline & & $\begin{array}{l}\text { 『図学研究』掲載論文に対する論文賞（研究論文賞・教育論文賞）を創設（第 } 1 \text { 回は教育論 } \\
\text { 文賞，以降，隔年で交互に授賞）（賞状と盾のデザイン・制作 : 村松俊夫） }\end{array}$ & \\
\hline & & 創立 40 周年記念事業準備委員会を設置, 準備を開始 & \\
\hline & 8 & $\begin{array}{l}\text { 第 } 12 \text { 回図学国際会議 ICGG ブラジル国サルバドールにて開催, 招待講演 } 4 \text { 編, 発表論文 } 92 \\
\text { 編, 参加登録者 } 90 \text { 名, 日本より } 21 \text { 論文発表, 鈴木賢次郎氏 The Steve M. Slaby Award を受 } \\
\text { 賞 }\end{array}$ & $40-4(114)$ \\
\hline
\end{tabular}




\begin{tabular}{|c|c|c|c|}
\hline 年 & 月 & & $\begin{array}{l}\text { 巻 }- \text { 号 } \\
\text { (通号) }\end{array}$ \\
\hline \multirow[t]{5}{*}{$\begin{array}{l}2006 \\
(\text { H.18) }\end{array}$} & 9 & $\begin{array}{l}\text { 創立 } 40 \text { 周年記念事業計画固まる } \\
\text { 記念大会の開催（於 東京大学） } \\
\text { 記念講演（海外より研究者を招聘） } \\
\text { 記念出版事業 } \\
\text { 創立 } 40 \text { 周年記念誌（委員長：梶山喜一郎） } \\
\text { 『Pov-Ray で学ぶ図形科学〈仮称〉』(鈴木広隆ほか) } \\
\text { 『CAD/CG 時代の図形科学（仮称〉』(鈴木賢次郎ほか) }] \\
\text { 記念表彰 [論文賞・功労賞など] }\end{array}$ & \\
\hline & 9 & $\begin{array}{l}\text { 図学教育研究会特別講演会「インスブルック大学に抢ける図学一幾何学と CAD 教育」 } \\
\text { (Hans-Peter Schröker)（於 東京大学) }\end{array}$ & $40-4(114)$ \\
\hline & 12 & $\begin{array}{l}\text { 本部例会 (於 静岡文化芸術大学), 特別講演「自由曲面の研究について」(東正毅), 研究発 } \\
\text { 表 } 13 \text { 編 }\end{array}$ & $41-1(115)$ \\
\hline & & 第 38 回図学教育研究会「CG/CAD, 造形デザイン教育と評価方法」, 発表 4 編 & $41-1(115)$ \\
\hline & & 40 周年大会の準備作業順調に進む & \\
\hline \multirow{8}{*}{$\begin{array}{l}2007 \\
(\mathrm{H} .19)\end{array}$} & 1 & 第 1 回デジタルモデリングコンテスト作品募集（一般公募）新設 & \\
\hline & 3 & 40 周年記念大会に向けて 『図学研究』誌上討論が行われる & $41-1(115)$ \\
\hline & & $\begin{array}{l}\text { 東京大学創立 } 130 \text { 年記念『測る人・画く人』展共催（於 東京大学教養学部自然科学博物館） } \\
(\sim 6 \text { 月 })\end{array}$ & \\
\hline & 5 & $\begin{array}{l}\text { 日本図学会 } 2007 \text { 年度・創立 } 40 \text { 周年記念大会 (於 東京大学) } \\
\text { 記念式典, } 40 \text { 周年記念表彰 (学会功労賞および論文賞), 学術講演 } 53 \text { 件, 会員数 } 336 \text { 名. 役 } \\
\text { 員改選（会長 : 加藤道夫), 募金募集 } \\
\text { 招待講演 } 3 \text { 題 } \\
\text { “The State of Engineering Design Graphics in the United States” (Theodore J. Branoff) (ノー } \\
\text { スカロライナ州立大学) } \\
\text { “Application of CAD Technology and Education of Engineering Graphics in China” (Bing-shu } \\
\text { Tong）（精華大学） } \\
\text { “The Status of Todays Descriptive Geometry Related Education（CAD/CG/DG）in Europe” } \\
\text { (Hellmuth Stachel）（ウィーン工科大学） } \\
\text { 記念シンポジゥム「3D-CAD, CG 時代の図法幾何学」(西原一嘉・鈴木広隆・神山明・近藤 } \\
\text { 邦雄・鈴木賢次郎） }\end{array}$ & $\begin{array}{l}41-2(116) \\
41-2(116) \\
41-3(117)\end{array}$ \\
\hline & & 第 1 回デジタルモデリングコンテスト実施，応募 13 件（賞状デザイン：町田芳明） & $41-2(116)$ \\
\hline & & 『図学研究』40 周年記念号『図学研究の広がり』刊行 (委員長 : 梶山喜一郎) & \\
\hline & 7 & $\begin{array}{l}\text { 第 } 8 \text { 回日中図学教育研究国際会議 蘇州にて開催, 日本より招待講演 } 2 \text { 題, 研究発表 } 21 \text { 編, } \\
\text { 本会をもって同会議一時中断 }\end{array}$ & $41-3(117)$ \\
\hline & 9 & 第 39 回図学教育研究会（関西支部第 83 回支部例会と共催） & $41-4(118)$ \\
\hline
\end{tabular}




\begin{tabular}{|c|c|c|c|}
\hline 年 & 月 & & $\begin{array}{l}\text { 巻 - 号 } \\
\text { (通号) }\end{array}$ \\
\hline \multirow[t]{2}{*}{$\begin{array}{l}2007 \\
\text { (H.19) }\end{array}$} & \multirow[t]{2}{*}{12} & $\begin{array}{l}\text { 本部例会 (於 富山大学), 学術講演 } 30 \text { 件 } \\
\text { 第 } 1 \text { 回モノづくりと三次元 CAD に関するフォーラム, 講演 } 4 \text { 題 }\end{array}$ & $42-1(119)$ \\
\hline & & $\begin{array}{l}\text { 第 } 40 \text { 回図学教育研究会「3D-CAD/3DCG 時代の図形科学・図法幾何学の課題と今後の展望」, } \\
\text { 講演 } 5 \text { 題 }\end{array}$ & $42-1(119)$ \\
\hline \multirow[t]{9}{*}{$\begin{array}{l}2008 \\
(\text { H.20) }\end{array}$} & \multirow[t]{2}{*}{3} & 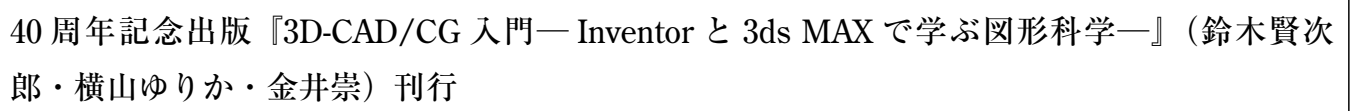 & \\
\hline & & $\begin{array}{l}40 \text { 周年記念出版『POV-Ray による } 3 \text { 次元 CG 制作一モデリングからアニメーションまで一』 } \\
\text { (鈴木広隆・倉田和夫・佐藤尚) 刊行 }\end{array}$ & \\
\hline & \multirow[t]{3}{*}{5} & $\begin{array}{l}\text { 日本図学会 } 2008 \text { 年度大会（於 北海道大学） } \\
\text { 会員数 } 325 \text { 名, 学術講演 } 47 \text { 件 }\end{array}$ & $42-2(120)$ \\
\hline & & 第 41 回図学教育研究会「POV-Ray による 3 次元 CG 制作」, 講演 6 題 & $42-2(120)$ \\
\hline & & 第 2 回デジタルモデリングコンテスト, 応募 20 件 & $42-2(120)$ \\
\hline & 8 & $\begin{array}{l}\text { 第 } 13 \text { 回図学国際会議（ICGG2008）をドイツ国ドレスデン市（ドレスデン工科大学）にて開 } \\
\text { 催，参加者総数 } 257 \text { 名，日本より招待講演 } 2 \text { 題，研究発表 } 32 \text { 編 }\end{array}$ & $42-4(122)$ \\
\hline & 10 & 2009 年度より本部例会を廃止し, 大会を年 2 回開催することを決定 & \\
\hline & \multirow[t]{2}{*}{11} & $\begin{array}{l}\text { 本部例会（於 立教大学池袋キャンパス）, 学術講演 } 32 \text { 件 } \\
\text { 第 } 2 \text { 回モノづくりと三次元 CAD に関するフォーラム, 講演 } 6 \text { 題 }\end{array}$ & $43-1(123)$ \\
\hline & & $\begin{array}{l}\text { 第 } 42 \text { 回図学教育研究会「3D-CAD/CGによる図（形科）学教育〜Autodesk Inventor/3ds } \\
\text { Max を例に」, 講演 } 1 \text { 題+実習 }\end{array}$ & $43-1(123)$ \\
\hline \multirow{8}{*}{$\begin{array}{l}2009 \\
\text { (H.21) }\end{array}$} & 2 & 第 14 回図学国際会議準備委員会設置（組織委員長 : 加藤道夫，実行委員長 : 鈴木広隆） & \\
\hline & \multirow[t]{3}{*}{5} & $\begin{array}{l}\text { 日本図学会 } 2009 \text { 年度春季大会（於 筑波技術大学天久保キャンパス） } \\
\text { 会員数 } 325 \text { 名, 役員改選（会長：堤江美子） } \\
\text { 特別講演「「視覚伝達デザイン」を「触覚伝達デザイン」の世界へ一筑波技術大学「触って } \\
\text { 観る」アートプロジェクトー」(安田輝男), 学術講演 } 45 \text { 件 }\end{array}$ & $43-2(124)$ \\
\hline & & 第 43 回図学教育研究会「SketchUp を用いた図学教育とその害践」, 講演 1 題 & $43-2(124)$ \\
\hline & & 第 3 回デジタルモデリングコンテスト, 応募 35 件 & $43-2(124)$ \\
\hline & \multirow[t]{4}{*}{11} & 40 周年記念出版『図学用語辞典』刊行（委員長 : 加藤道夫） & \\
\hline & & $\begin{array}{l}\text { 日本図学会 } 2009 \text { 年度秋季大会（於 東京都市大学世田谷キャンパス） } \\
\text { 学術講演 } 31 \text { 件 } \\
\text { 第 } 3 \text { 回モノづくりと三次元 CAD に関するフォーラム, 講演 } 5 \text { 題 }\end{array}$ & $44-1(127)$ \\
\hline & & 第 44 回図学教育研究会 $「 \mathrm{CG} / \mathrm{CAD}$ を図（形科）学で教えることの意義」, 講演 3 題 & $44-1(127)$ \\
\hline & & 科学技術振興機構が「平成 21 年度電子アーカイブ対象候補誌」として『図学研究』を選定 & \\
\hline
\end{tabular}




\begin{tabular}{|c|c|c|c|}
\hline 年 & 月 & & $\begin{array}{l}\text { 巻 }- \text { 号 } \\
\text { (通号) }\end{array}$ \\
\hline \multirow{6}{*}{$\begin{array}{l}2010 \\
\text { (H.22) }\end{array}$} & \multirow[t]{2}{*}{8} & 日本図学会 2010 年度総会開催, 会員数 317 名 & $44-3(129)$ \\
\hline & & 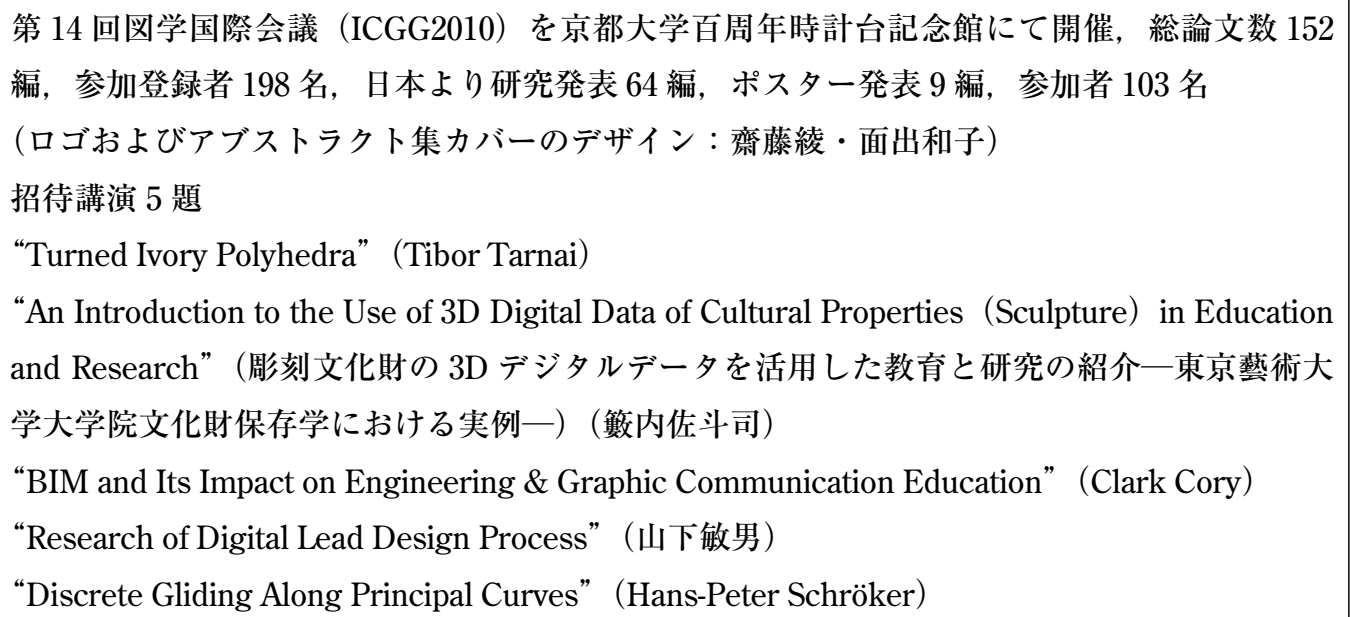 & $44-4(130)$ \\
\hline & 9 & 中国図学学会より日中国際会議再開の要望 & \\
\hline & \multirow[t]{3}{*}{11} & $\begin{array}{l}\text { 日本図学会 } 2010 \text { 年度秋季大会（於 法政大学市ヶ谷キャンパス） } \\
\text { 学術講演 } 28 \text { 件 }\end{array}$ & $45^{-1}(131)$ \\
\hline & & $\begin{array}{l}\text { 第 } 45 \text { 回図学教育研究会「メディア系・アート系学科での CG・CAD ッールを用いた教育に } \\
\text { ついて」, 講演 } 4 \text { 題 }\end{array}$ & $\begin{array}{l}45-1(131), \\
45-2(132)\end{array}$ \\
\hline & & 第 4 回デジタルモデリングコンテスト, 応募 14 件 & $45-2(132)$ \\
\hline \multirow[t]{9}{*}{$\begin{array}{l}2011 \\
(\mathrm{H} .23)\end{array}$} & \multirow[t]{2}{*}{5} & $\begin{array}{l}\text { 日本図学会 } 2011 \text { 年度春季大会（於 東京電機大学神田キャンパス） } \\
\text { 会員数 } 322 \text { 名, 役員改選（会長：堤江美子), 企画広報委員会設置（企画委員会と電子化委 } \\
\text { 員会を再編して設置） } \\
\text { 学術講演 } 36 \text { 件 }\end{array}$ & $45^{-3}(133)$ \\
\hline & & $\begin{array}{l}\text { 第 } 46 \text { 回図学教育研究会「建築系学科における } 3 \mathrm{D} \cdot \mathrm{CG} / \mathrm{CAD} \text { ッールの意義と教育の在り方」, } \\
\text { 講演 } 3 \text { 題 }\end{array}$ & $45^{-}-3(133)$ \\
\hline & 6 & 錯覚美術館見学ツアー開催 & \\
\hline & 7 & $\begin{array}{l}\text { 春季大会開催場所変更（東北地方太平洋沖地震とそれに伴う災害への対応）による剩余金 } \\
126,473 \text { 円を東日本大震災支援のため朝日新聞厚生文化事業団に寄付 }\end{array}$ & \\
\hline & 8 & $\begin{array}{l}\text { 『図学研究』（通巻 } 1 \text { 号〜122 号及び別冊）J-STAGE にて公開開始 } \\
\text { (https://www.jstage.jst.go.jp/browse/jsgs/-char/ja/) }\end{array}$ & \\
\hline & \multirow[t]{4}{*}{11} & $\begin{array}{l}\text { 日本図学会 } 2011 \text { 年度秋季大会（於 大阪市立大学杉本キャンパス） } \\
\text { 招待講演「中国の工業教育と中国図学教育の改革」(韓宝玲)（中国図学学会国際担当，北京 } \\
\text { 理工大学), 学術講演 } 46 \text { 件 }\end{array}$ & $46-1(135)$ \\
\hline & & $\begin{array}{l}\text { 第 } 47 \text { 回図学教育研究会「初等・中等教育における図形・図法（幾何学）に関わる授業とそ } \\
\text { の必要性」, 講演 } 3 \text { 題 }\end{array}$ & $46-1(135)$ \\
\hline & & 第 5 回デジタルモデリングコンテスト, 応募 11 件 & $46-1(135)$ \\
\hline & & 日中国際会議（名称：アジア図学会議）2013 年より再開を決定 & \\
\hline
\end{tabular}




\begin{tabular}{|c|c|c|c|}
\hline 年 & 月 & & $\begin{array}{l}\text { 巻 }- \text { 号 } \\
\text { (通号) }\end{array}$ \\
\hline \multirow[t]{10}{*}{$\begin{array}{l}2012 \\
(\text { H.24) }\end{array}$} & \multirow[t]{2}{*}{5} & $\begin{array}{l}\text { 日本図学会 } 2012 \text { 年度春季大会（於 大同大学滝春キャンパス） } \\
\text { 会員数 } 306 \text { 名, 『図学研究』投稿規定を改定 } \\
\text { 学術講演 } 30 \text { 件 }\end{array}$ & $46-3(137)$ \\
\hline & & $\begin{array}{l}\text { 第 } 48 \text { 回図学教育研究会「3D-CAD/CG 時代における図法幾何学教育の意義—モンジュの図法 } \\
\text { 幾何学を読み解く」, 講演 } 3 \text { 題 }\end{array}$ & $46-3(137)$ \\
\hline & 8 & $\begin{array}{l}\text { 第 } 15 \text { 回図学国際会議（ICGG2012）をカナダ国モントリオール市（マッギル大学）にて開催， } \\
\text { 総論文数 } 118 \text { 編（口頭 } 109 \text { 件，ポスター } 9 \text { 件)，日本より研究発表 } 32 \text { 編，参加者 } 42 \text { 名，堤 } \\
\text { 江美子氏 The Steve M. Slaby Award を受賞 }\end{array}$ & $46-4(138)$ \\
\hline & 9 & 『図学研究』執筆要領を改定 & \\
\hline & \multirow[t]{3}{*}{10} & 日本図学会ウェブページ刷新 & \\
\hline & & 『図学研究』論文投稿電子化 & \\
\hline & & 大会講演論文集の原稿提出電子化（2013 年度春季大会より運用） & \\
\hline & \multirow[t]{3}{*}{12} & $\begin{array}{l}\text { 日本図学会 } 2012 \text { 年度秋季大会（於 東京工科大学蒲田キャンパス） } \\
\text { 学術講演 } 44 \text { 件 }\end{array}$ & $47-1(139)$ \\
\hline & & $\begin{array}{l}\text { 第 } 49 \text { 回図学教育研究会「実務者と職業能力開発大学校における（機械）設計製図の現状と } \\
\text { 課題」, 講演 } 2 \text { 題 }\end{array}$ & $47-1(139)$ \\
\hline & & 第 6 回デジタルモデリングコンテスト, 応募 2 件 & $47-1(139)$ \\
\hline \multirow{10}{*}{$\begin{array}{l}2013 \\
(\mathrm{H} .25)\end{array}$} & 4 & ホームページ委員会設置 & \\
\hline & \multirow[t]{2}{*}{5} & $\begin{array}{l}\text { 日本図学会 } 2013 \text { 年度春季大会（於 産業技術短期大学） } \\
\text { 会員数 } 289 \text { 名, 役員改選（会長：山口泰), 学術講演 } 30 \text { 件 }\end{array}$ & $\begin{array}{l}47-2 \cdot 3 \\
(140)\end{array}$ \\
\hline & & 第 50 回図学教育研究会「デジタルモデリングに関する研究の必要性」, 講演 4 題 & $\begin{array}{l}47-2 \cdot 3 \\
(140)\end{array}$ \\
\hline & \multirow[t]{2}{*}{8} & $\begin{array}{l}\text { 第 } 9 \text { 回アジア図学会議（Asian Forum on Graphic Science 2013）を中華人民共和国大連市仲 } \\
\text { 夏花園酒店にて開催（日中図学教育研究国際会議を発展的に改定して再開), 総論文数 } 25 \text { 編, } \\
\text { 参加登録者 } 200 \text { 名超, 日本より特別講演 } 1 \text { 題, 研究発表 } 14 \text { 編, 参加者 } 18 \text { 名 }\end{array}$ & $47-4(141)$ \\
\hline & & $\begin{array}{l}\text { 3D プリンタを深く知るためのラピッドプロトタイピング研究会（於 埼玉県産業技術総合セ } \\
\text { ンター） }\end{array}$ & $48-1(142)$ \\
\hline & \multirow[t]{2}{*}{10} & 『図学研究』の J-STAGE 登録開始（「論文」「作品紹介」「講座」にDOI 付与） & \\
\hline & & 「優秀研究発表賞」「研究奨励賞」表彰規定改定（委員会の名称変更に伴う改定） & \\
\hline & \multirow[t]{2}{*}{11} & $\begin{array}{l}\text { 日本図学会 } 2013 \text { 年度秋季大会（於 岩手県盛岡市ホテル大観） } \\
\text { 学術講演 } 24 \text { 件 }\end{array}$ & $48^{-1}(142)$ \\
\hline & & 第 7 回デジタルモデリングコンテスト, 応募造形部門 8 件・アイデア部門 3 件 & $48-1(142)$ \\
\hline & 12 & 大会講演論文の著作権に関する規定の制定（講演論文集の著作権帰属明確化のため） & \\
\hline
\end{tabular}




\begin{tabular}{|c|c|c|c|}
\hline 年 & 月 & & $\begin{array}{l}\text { 巻 }- \text { 号 } \\
\text { (通号) }\end{array}$ \\
\hline \multirow{11}{*}{$\begin{array}{l}2014 \\
(\text { H.26) }\end{array}$} & 1 & 『図学研究』執筆要領を改定 & \\
\hline & 3 & JABEE 退会（入会は 2002 年） & \\
\hline & 4 & $\begin{array}{l}\text { デジタルモデリングコンテスト実行委員会を発展的に解消し，デジタルモデリング研究会設 } \\
\text { 置 }\end{array}$ & \\
\hline & \multirow[t]{2}{*}{5} & $\begin{array}{l}\text { 日本図学会 } 2014 \text { 年度春季大会（於 九州大学西新プラザ） } \\
\text { 会員数 } 299 \text { 名, 学術講演 } 34 \text { 件 }\end{array}$ & $\begin{array}{l}48-2 \cdot 3 \\
(143)\end{array}$ \\
\hline & & $\begin{array}{l}\text { 第 } 51 \text { 回図学教育研究会「図学関連教育と空間認識力一切断面実形視テスト（MCT）による } \\
\text { 調査結果を中心に一」, 講演 } 3 \text { 題 }\end{array}$ & $\begin{array}{l}48-2 \cdot 3 \\
(143)\end{array}$ \\
\hline & 6 & $\begin{array}{l}\text { 大会講演論文集を国立国会図書館に献本し, ISSN の付与を受けることにした（1997 年に遡っ } \\
\text { て ISSN が付与され, 国立国会図書館に献本した })\end{array}$ & \\
\hline & 8 & $\begin{array}{l}\text { 第 } 16 \text { 回図学国際会議（ICGG2014）をオーストリア国インスブルック市（インスブルック大 } \\
\text { 学）にて開催，参加登録者 } 227 \text { 名 (37 ヶ国), フルペーパー } 144 \text { 編，ポスター } 19 \text { 編，日本よ } \\
\text { り研究発表 } 28 \text { 編・ポスター } 1 \text { 編, 参加者 } 39 \text { 名 }\end{array}$ & $48^{-4}(144)$ \\
\hline & 9 & 『図学研究』第 140 号より J-STAGE にて公開開始 & \\
\hline & \multirow[t]{3}{*}{11} & $\begin{array}{l}\text { 日本図学会 } 2014 \text { 年度秋季大会（於 東京藝術大学） } \\
\text { 特別講演「彫刻をつくることと図学」(本郷寛), 学術講演 } 40 \text { 件, 作品展示を特別開催 }(22 \\
\text { 件） }\end{array}$ & $49-1(145)$ \\
\hline & & 第 8 回デジタルモデリングコンテスト, 応募造形部門 9 件・アイデア部門 2 件 & $49-1(145)$ \\
\hline & & 第 1 回デジタルモデリング研究会, テーマ「デジタルデータ」, 講演 3 題 & $49-1(145)$ \\
\hline \multirow[t]{7}{*}{$\begin{array}{l}2015 \\
(\text { H.27) }\end{array}$} & 3 & $\begin{array}{l}\text { リガ工科大学 Zoja Veide 先生講演会（於 東京大学教養学部),「リガ工科大学・神戸大学間 } \\
\text { の学術交流事業」(鈴木広隆),「リガ工科大学における拈学製図教育一ラトビアの文化と幾 } \\
\text { 何学の間のいくつかの関係について」(Zoja VEIDE) }\end{array}$ & \\
\hline & \multirow[t]{2}{*}{5} & $\begin{array}{l}\text { 日本図学会 } 2015 \text { 年度春季大会 (於 北海道大学) } \\
\text { 会員数 } 312 \text { 名, 役員改選 (会長 : 山口泰), 学術講演 } 32 \text { 件 }\end{array}$ & $49-3(147)$ \\
\hline & & 第 52 回図学教育研究会「図法幾何学教育の現状と将来一総合大学のケース一」, 講演 6 題 & \\
\hline & 8 & $\begin{array}{l}\text { 第 } 10 \text { 回アジア図学会議（AFGS2015）をタイ国バンコク市チャトリアムホテルリバーサイド } \\
\text { にて開催（日本・中国以外での初の開催), 総論文数 } 32 \text { 編，参加登録者 } 55 \text { 名，日本より研 } \\
\text { 究発表 } 19 \text { 編，ポスター } 10 \text { 編，参加 } 36 \text { 名 }\end{array}$ & $49-4(148)$ \\
\hline & 10 & $\begin{array}{l}\text { Autodesk 社との意見交換会, デジタルモデリングコンテストおよび Inventor Professional お } \\
\text { よび 3ds Max Design を利用した図形科学教育を紹介 }\end{array}$ & \\
\hline & \multirow[t]{2}{*}{11} & $\begin{array}{l}\text { 日本図学会 } 2015 \text { 年度秋季大会（於 大阪大学吹田キャンパス） } \\
\text { 学術講演 } 34 \text { 件 }\end{array}$ & $\begin{array}{l}50-1 \cdot 2 \\
(149)\end{array}$ \\
\hline & & 第 2 回デジタルモデリング研究会, テーマ「情報の可視化技術」, 講演 2 題 & $\begin{array}{l}50-1 \cdot 2 \\
(149)\end{array}$ \\
\hline
\end{tabular}




\section{0 年の歩み}

\begin{tabular}{|c|c|c|c|}
\hline 年 & 月 & & $\begin{array}{l}\text { 巻 - 号 } \\
\text { (通号) }\end{array}$ \\
\hline $\begin{array}{l}2015 \\
(\mathrm{H} .27)\end{array}$ & 11 & 第 9 回デジタルモデリングコンテスト, 応募造形部門 7 件・アイデア部門 2 件 & $\begin{array}{l}50-1 \cdot 2 \\
(149)\end{array}$ \\
\hline \multirow[t]{9}{*}{$\begin{array}{l}2016 \\
(\mathrm{H} .28)\end{array}$} & \multirow[t]{2}{*}{4} & $\begin{array}{l}\text { 科学研究費補助金研究成果公開発表（C）「アジア図学会議（AFGS）／アジアデジタルモデリ } \\
\text { ングコンテスト }(\mathrm{ADMC}) 」 \text { 採択 }\end{array}$ & \\
\hline & & 外部資金に基づく事業の会計に関する規定の制定（科学研究費補助金による事業実施のため） & \\
\hline & \multirow[t]{3}{*}{5} & 2016 年度大会講演論文から『図学研究』採録論文への査読希望募集開始 & \\
\hline & & $\begin{array}{l}\text { 日本図学会 } 2016 \text { 年度春季大会（於 八戸グランドホテル） } \\
\text { 会員数 } 319 \text { 名, 学術講演 } 32 \text { 件 }\end{array}$ & $50-3(150)$ \\
\hline & & $\begin{array}{l}50 \text { 周年記念事業準備委員会設置, } 50 \text { 周年記念大会, アジア図学会議 (AFGS2017), アジア } \\
\text { デジタルモデリングコンテスト }(\mathrm{ADMC}) \text {, 図学研究 } 50 \text { 周年記念号, 図学会 } 50 \text { 年間のアー } \\
\text { カイブ, J-STAGE 未登録号の登録などの準備を開始 }\end{array}$ & \\
\hline & 8 & $\begin{array}{l}\text { 第 } 17 \text { 回図学国際会議（ICGG2016）を中華人民共和国北京市（北京理工大学）にて開催，参 } \\
\text { 加者総数 } 152 \text { 名, 総論文数 } 144 \text { 編, 日本より招待講演 } 1 \text { 題, 研究発表 } 24 \text { 編, ポスター発表 } 3 \\
\text { 編 }\end{array}$ & $50-4(151)$ \\
\hline & \multirow[t]{2}{*}{11} & $\begin{array}{l}\text { 日本図学会 } 2016 \text { 年度秋季大会（於 首都大学東京南大沢キャンパス） } \\
\text { 学術講演 } 24 \text { 件，ポスター発表 } 19 \text { 件 }\end{array}$ & $51-1(152)$ \\
\hline & & $\begin{array}{l}\text { 第 } 3 \text { 回デジタルモデリング研究会, テーマ「デジタルファブリケーションの制作環境を利用 } \\
\text { したものづくり教育」, 講演 } 3 \text { 題 }\end{array}$ & $51-1(152)$ \\
\hline & 12 & 50 周年記念事業の準備作業順調に進む & \\
\hline
\end{tabular}

\section{よこやまゆりか}

東京大学大学院 総合文化研究科広域科学専攻広域システム科学系 (情報・図形) 教授, 博士 (工学)

構築環境の知覚・認知・記憶および構築環境における人間行動の研究

\section{しいなくみこ}

独立行政法人 大学入試センター研究開発部 教授, 博士 (学術)

空間認識力の評価, 非教科型の能力測定に関する研究に従事.

shiina@rd.dnc.ac.jp

\section{たねだ もとはる}

法政大学, 東洋大学, 桜美林大学 非常勤講師, 博士 (工学)

近代建築と図面表現に関わる研究に従事.

mt.totoharu@gmail.com 